\author{
MIKOEAJ GETKA-KENIG \\ Instytut Historyczny \\ Uniwersytetu Warszawskiego
}

\title{
„NAJPIERWSZE PRZY TRONIE DOSTOJEŃSTWO”- NAPOLEOŃSKI CENTRALIZM A POJĘCIE ELITY W KSIĘSTWIE WARSZAWSKIM
}

\begin{abstract}
„Najtrudniejszy orzech do zgryzienia dla rosyjskich pojęć układających ceremoniał koronacyjny było to, że w Polsce rangi nie istniały; po długich rozprawach, na przedstawienie księżny Adamowej Czartoryskiej, przedkładającej, iż w Polsce każden siebie za równego uważa z największym panem, uradzono i pozwolono w dzień prezentacji każdej damie iść samowolnie, czy jest, lub nie jest, dygnitarza wielkiego żoną lub córką, bez przestrzegania żadnej kolei co do starszeństwa rangi w czasie prezentacji u dworu" ". Przywołana anegdota pochodzi ze wspomnień Natalii z Bispingów Kickiej (1801-1888). Pamiętnikarka, będąca w maju 1829 r. naocznym świadkiem przygotowań do warszawskiej koronacji Mikołaja I, uwieczniła na piśmie z pozoru błahy kłopot organizacyjny niemożność ustalenia precedencji polskich dostojników. W rzeczywistości opisywany incydent wprowadza nas w kontekst interesującego problemu z dziedziny mentalności, który w pełni dał o sobie znać już w dobie Księstwa Warszawskiego.

Niniejszą rozprawę traktuję jako przyczynek do badań nad wyobrażeniami społecznymi na ziemiach polskich w XIX w. Interesuje mnie zagadnienie kryzysu dotychczasowego pojmowania elity i hierarchii społecznej w sytuacji rewolucyjnej zmiany charakteru służby publicznej we „wskrzeszonym” przez Napoleona państwie polskim. Z tego względu główny punkt odniesienia dla mojej narracji stanowi niezrealizowana próba ustanowienia precedencji urzędów, a ściślej, problem z wyznaczeniem, komu należy się czołowa pozycja. Przymiotnik „publiczny”
\end{abstract}

\footnotetext{
${ }^{1}$ N. Kicka, Pamiętniki, Warszawa 1972, s. 166.
} 
(urząd, stanowisko, służba), kluczowy dla opisywanych przeze mnie realiów, rozumiem jako odnoszący się do sfery państwa i władzy (polityki), w zasadzie stanowiący synonim określenia „oficjalny”. Za jego desygnat uznaję ogół stanowisk, które w interesującym mnie okresie umieszczano na łamach tzw. kalendarzyków politycznych. Właśnie ta szeroko pojęta grupa urzędów (bynajmniej nie wyłącznie administracyjnych) stanowiła przedmiot zainteresowania niedoszłych twórców „warszawskiej” precedencji.

Tak bezpośrednie powiązanie służby publicznej z prestiżem społecznym w omawianym okresie wydaje mi się w pełni uzasadnione. Decydowała o tym zarówno wciąż żywa dla tego okresu tradycja staropolska, jak i fundamentalne znaczenie instytucji państwa dla ówczesnych wyobrażeń o społeczeństwie-narodzie. Najprościej rzecz ujmując, mowa o czasach, dla których pojęcia elity społecznej i politycznej były w gruncie rzeczy tożsame.

Sama koncepcja precedencji, hierarchicznie porządkującej ogół funkcji państwowych (zarówno administracyjnych, sądowych, wojskowych jak i parlamentarnych), nie była znana w przedrozbiorowej Rzeczypospolitej i bezpośrednio wynikała ze specyficznie napoleońskiego sposobu myślenia o władzy i państwie. Kwestia oficjalnej hierarchii i wynikającego z niej ceremonialnego porządku (préséance) stanowiła nad Sekwaną istotne zagadnienie za rządów Bonapartego. Po części za jej wprowadzenie odpowiadał wojskowy dryl, szybko opanowujący administrację cywilną. Bardziej decydująca wydaje się jednak odczuwana przez nowy (posttermidoriański) ustrój nieodparta potrzeba uporządkowania rewolucyjnego chaosu. Sama instytucja konsulatu, a tym bardziej dziedzicznego cesarstwa, sui generis nowoczesnego pryncypatu (ani republiki, ani monarchii według tradycyjnych francuskich wyobrażeń), determinowała odgórną reformę społeczeństwa, a zwłaszcza jego wyższych warstw. Od tej pory wszelka hierarchia dystynkcji (a zatem i prestiżu) miała opierać się na stopniu oddalenia od centrum faktycznej i jednorodnej władzy, aby dzięki temu uniknąć ambiwalencji typowej dla ancien régime’u, gdzie najwyższych elit było tyle, ile indywidualnych pretensji do pierwszeństwa. Oczywiście, Napoleon był pod tym względem kontynuatorem o wiele starszej myśli osiemnastowiecznego oświecenia francuskiego, które również dostrzegało w tej sytuacji istotny problem polityczno-społeczny $^{2}$. Sama idea jednej i powszechnie obowiązującej hierarchii mogła

${ }^{2} \mathrm{Na}$ ten temat patrz: $\mathrm{O}$. Ihl, Les rangs du pouvoir. Régimes de préséances et bureaucratie d'État dans la France des XIX et XX $X^{e}$ siècles, w: Le protocole ou la mise en forme de l'ordre politique, red. Y. Deloye, C. Haroche, O. Ihl, Paris-Montréal 1996, s. 233-261; G. Bossenga, The politics of privilege. Old regime and revolution in Lille, Cambridge 1991, s. 180-182 
jawić się jako próba racjonalizacji struktur społecznych, opisania ich za pomocą ścisłych, niemal matematycznych reguł lub nawet świadomego narzucenia im takiego rygoru.

Jednak w początkach XIX w. społeczeństwo i jego elity nie miały już charakteru znanego teoretykom z kręgu encyklopedystów. Nie można było odchodzić od pojęcia równości wszystkich obywatelskich jednostek. Tym samym wszelka hierarchia społeczna nie dotyczyła już, jak dawniej, osoby jako takiej, ale wykonywanej przez nią funkcji, która stawała się tymczasowa, a nawet niekiedy kadencyjna. Przeniesienie akcentu z osoby na stanowisko pozwalało utwierdzić wszechogarniającą hegemonię biurokracji, która najlepiej służyła centralistycznemu ideałowi cesarskiej władzy. Praktyczne wprowadzenie tej zasady nie było rzecz jasna takie łatwe. Chociażby na najwyższym poziomie pojawił się problem ustawowo dożywotnich stanowisk senatorskich i niejednoznaczności ich prestiżowej pozycji. Szczególna sytuacja Senatu polegała na skromnych kompetencjach przy oficjalnie zadekretowanej niezależności (podkreślanej dożywotnością) od władzy wykonawczej, co miało współgrać w jednym systemie z legitymizowaną wszechwładzą cesarza. Tym samym ambiwalentne znaczenie senatorstwa jako kondycji polityczno-społecznej stało się jednym z paradoksów napoleońskiej Francji ${ }^{3}$.

Rewolucyjny charakter tych wszystkich zmian został umyślnie osłabiony przez ustanowienie dziedzicznej szlachty cesarskiej (a także królewsko-włoskiej, holenderskiej, hiszpańskiej itd.). Mimo pozornego powrotu do przeszłości napoleońska dystynkcja miała już wyraźnie odmienny charakter niż przed pamiętną abolicją szlachectwa w 1790 r. ${ }^{4}$ Stanowiła wyraz chęci pogodzenia dwóch tradycji, przed-i porewolucyjnej, których współdziałanie mogło okazać się szczególnie korzystne dla nowego porządku. Z jednej strony, aby cokolwiek znaczyć, trzeba było pełnić jakąś funkcję urzędową, obdarzoną faktyczną mocą sprawczą, której waga zależała od miejsca zajmowanego na drabinie stanowisk. Z drugiej strony, aby nowa biurokracja szybko pozyskała odpowiedni autorytet (a tym samym wzmagała swoją skuteczność), dobór urzędników wszelkiego szczebla nierzadko uzależniany był od ich osobistego znaczenia. $\mathrm{W}$ ten sposób dawne czynniki

(bardzo dziękuję mojemu koledze Mateuszowi Falkowskiemu z Instytutu Historycznego UW za uprzejme umożliwienie mi dostępu do tej pozycji); M. Rowe, Between Empire and Home Town. Napoleonic Rule on the Rhine 1799-1814, "The Historical Journal” 42, 1993, 3, s. 653-654.

${ }^{3} \mathrm{Na}$ temat Senatu i senatorów I Cesarstwa patrz: J. Thiry, Sénat de Napoléon (18001814), Paris 1932.

${ }^{4} \mathrm{~J}$. Tulard, Napoléon et la noblesse d'Empire: Avec la liste complète des membres de la noblesse impériale (1808-1815), Paris 2003. 
określające prestiż społeczny, takie jak urodzenie czy majątek, a także wzgląd na wciąż pamiętane dostojeństwa ancien régime'u, mogły przysłużyć się w utwierdzaniu dopiero co ustanowionego porządku'

Napoleońskie nowinki (takie jak model struktury urzędniczej) zawitały na polską ziemię w szczególnym momencie. Drastyczna zmiana, jaką przyniosły społeczeństwu szlacheckiemu rozbiory, polegała m.in. na załamaniu dotychczasowych mechanizmów elitotwórczych. Rzecz jasna, systemy zaborcze oferowały nowe możliwości, które pozwalały ustrzec się przed gwałtowną deklasacją. Wiązało się to jednak z przyjęciem obcych reguł, które z oczywistych względów determinowały zmiany w zakresie charakteru elitarnej pozycji, a zatem i wyobrażeń na jej temat. Nieprzypadkowo w ciągu całego XIX stulecia zrąb arystokratycznej elity stanowili potomkowie czołowych polityków epoki stanisławowskiej (zwłaszcza tych odznaczających się w jej schyłkowym okresie). Jednak może się wydawać, że stała za tym faktem przede wszystkim determinacja poszczególnych jednostek chcących osiągnąć społeczno-polityczne pierwszeństwo, a jej katalizatorem były zarówno odziedziczone atuty kulturowo-ekonomiczne, jak i chęć współpracy ze strony nadrzędnych czynników władzy, które jedynie w ograniczonym stopniu miały ambicje zmian w przedmiocie doboru miejscowej elity. Bez względu na znaczny odsetek środowiska postmagnackiego ${ }^{6} \mathrm{w}$ obrębie dziewiętnastowiecznej elity elit społeczeństwo pierwszych porozbiorowych pokoleń i tak zaakceptowało wiele rozmaitych mniej lub bardziej spektakularnych awansów ${ }^{7}$.

Dla każdego podejmującego temat świadomości zmian w porozbiorowej rzeczywistości społecznej, zwłaszcza w odniesieniu do jej górnych warstw, przedział lat 1806-1831 powinien wydawać się szczególnie interesujący. Właśnie wtedy nastąpiła bezpośrednia interakcja pomiędzy zachodnioeuropejskim wzorcami ${ }^{8}$ a tradycyjnymi wyobrażeniami na temat polskości i potrzeby jej utwierdzania (odbudowywania) w dobie Księstwa Warszawskiego i Królestwa Polskiego. Elity państwa-narodu definiowały się więc na nowo, nie mogąc tak po prostu przenieść idealizowanej

${ }^{5} \mathrm{~J}$. Dume, Power on the Periphery: Elite-State Relations in the Napoleonic Empire, w: Napoleon and His Empire. Europe 1804-1814, red. P. G. Dwyer, A. Forrest, Basingstoke-New York 2007, s. 61-78; L. Bergson, Permanence et consolidation de l'ancienne noblesse, w: Une histoire des élites 1700-1848, red. G. Chaussinand-Nogaret, Paris 1975, s. 238-244.

${ }^{6}$ Pozwalam sobie na zastosowanie tego określenia jako synonimu pojęcia „rodzin historycznych", a więc tej części dziewiętnastowiecznej elity arystokratycznej, która bezpośrednio wywodziła się ze środowiska przedrozbiorowej magnaterii.

${ }^{7}$ W. Kula, Udział we władzy, w: Przemiany społeczne w Królestwie Polskim 1815-1864, red. W. Kula, J. Leskiewiczowa, Wrocław 1979, s. 405-419; M. Getka-Kenig, The Genesis of the Aristocracy in Congress Poland, APH 2009, 100, s. 79-112.

${ }^{8}$ Wliczając w to również zachodniocentryczną kulturę ówczesnej szlachty rosyjskiej. 
przedrozbiorowej tradycji w realia „odrodzonej” państwowości. „Polskość" (a więc genetyczna łączność z Rzecząpospolitą) Księstwa i Królestwa, nawet jeśli niekiedy dla współczesnych dość problematyczna, miała poważne reperkusje na poziomie relacji między prestiżem stanowiska publicznego a pozycją społeczną. Nowe instytucje, urzędy, dziedziczne, dożywotnie bądź czasowe honory, a także nietypowa dla sytuacji przedrozbiorowej silna pozycja monarchy, wpływały na indywidualne strategie budowania lub podtrzymywania elitarnej pozycji społecznej. Wydaje się, że wszyscy mający ambicje bądź pretensje do społecznego (a zatem i politycznego) pierwszeństwa musieli się odpowiednio odnaleźć w tych okolicznościach i stosownie pokierować indywidualnymi karierami.

Przypadek elity społecznej w Księstwie ${ }^{9}$ wydaje się nawet bardziej interesujący ze względu na fakt, że w Królestwie jedynie kontynuowano wiele społeczno-politycznych innowacji z epoki poprzedniej. Poważne zmiany dotyczyły samej istoty szlachectwa. Niemało dyskutowano na ten temat już podczas Sejmu Wielkiego. Zarówno problem szlachty nieposiadającej, jak i kwestia masowych nobilitacji mieszczan wywoływała wtedy poważne kontrowersje ${ }^{10}$. W „odrodzonym” po 1807 r. państwie można było się przekonać o trwałym efekcie tamtych debat. Bezproblemowe wprowadzenie do sejmu licznych przedstawicieli mieszczaństwa nie byłoby oczywiście możliwe, gdyby nie precedens miejskich plenipotentów z 1791 r. Lecz właśnie wówczas, w toku pierwszych zgromadzeń gminnych 1809 r., sytuacja ta nabierała charakteru normy, opierającej się na niedawnej, ale już odpowiednio spatynowanej tradycji. Oświeceniowe tendencje demokratyzacyjne, które wielu staropolskich polityków dzieliło ze swoimi kolegami w innych krajach Europy, po raz kolejny uzyskały konstytucyjną sankcję, tym razem wspartą autorytetem samego Napoleona ${ }^{11}$.

Duch i litera napoleońskiego prawa, czerpiąc pełnymi garściami z wielkosejmowych doświadczeń, szły jednak o wiele dalej. Nieszlachta pojawiła się nie tylko na ławach sejmowych, ale i w rządzie, który w nowym ustroju pełnił funkcję właściwego centrum decyzyjnego ${ }^{12}$. Wpierw

${ }^{9} \mathrm{Na}$ temat zmian w sytuacji polskiego społeczeństwa w tym czasie patrz: J. Czubaty, Księstwo Warszawskie (1807-1815), Warszawa 2011, s. 319-398.

${ }^{10} \mathrm{~J}$. Jedlicki, Klejnot $i$ bariery społeczne. Przeobrażenia szlachectwa polskiego w schyłkowym okresie feudalizmu, Warszawa 1968, s. 15-182.

${ }^{11}$ Co więcej, nieszlachta szybko uświadomiła sobie swoją pozycję polityczną, co obrazuje anegdota Juliana Ursyna Niemcewicza na temat starosty lubelskiego Wojciecha Mączyńskiego (Miączyńskiego), któremu odmówiono prawa kandydowania na deputowanego. J. U. Niemcewicz, Pamiętniki o czasach Księstwa Warszawskiego (1807-1809), Warszawa 1902, s. 193-194.

${ }^{12} \mathrm{Na}$ temat związków między rozwojem biurokracji a upadkiem ancien régime’u patrz: H. Rosenberg, Bureaucracy, Aristocracy and Autocracy. The Prussian Experience 
Karol Fryderyk Woyda został w 1807 r. referendarzem Rady Stanu, a kilka lat potem jego kolega Stanisław Staszic zasiadł w niej w charakterze radcy stanu, a więc pełnoprawnego członka. Co prawda były to jedynie pojedyncze przypadki. Jednak już sam fakt ich zaistnienia wydaje się znaczący, tym bardziej że urzędów tej rangi nie było wiele. W tym samym czasie pojawiły się również pomysły mające na celu symboliczne podwyższenie znaczenia mieszczan $\mathrm{w}$ przestrzeni publicznej ${ }^{13}$. Nie powinno się również zapomnieć o sferach wojskowych. Dwóch mieszczan z urodzenia, Józef Rautenstrauch i Maurycy Hauke, dosłużyło się wszakże generalskiego wężyka w armii książęcowarszawskiej. Obaj odrywali przy tym dość istotną rolę w swoim środowisku ${ }^{14}$.

Nie da się zaprzeczyć, że szlachectwo wciąż cieszyło się najwyższym poważaniem. Najlepszym tego świadectwem czysto herbowy skład Senatu, jak i Rady Ministrów, nie wspominając już o dostojeństwach dworskich $^{15}$. Podobna dyskryminacja charakteryzowała również rozdawnictwo orderów. Wiele innych funkcji, zwłaszcza prowincjonalnych i obieralnych (w tym rady wojewódzkie), było niemal wyłącznie obejmowanych przez szlachtę $^{16}$. Niektóre rozwiązania prawne również wzmacniały szlachecką pozycję, np. szlachcic miał szansę zostać deputowanym, podczas gdy nieszlachcic nie mógł konkurować o poselstwo. Jednak w przeciwieństwie do sytuacji sprzed rozbiorów teraz szlachecka dystynkcja nabierała znaczenia w szerokim kontekście społecznym. Dawniej dygnitarz był szlachcicem (a nawet magnatem) z założenia. W Księstwie zaczął nim bywać tylko z reguły, a wyjątków już nie dawało się wykluczyć. Szlachta została postawiona w sytuacji potencjalnej konkurencji w przestrzeni władzy (polityki). Nawet jeżeli faktyczne „zagrożenie” przyszło dopiero po po-

1660-1815, Harvard 1966; J. R. Gills, Aristocracy and Bureaucracy in Nineteenth-Century Prussia, „Past \& Present” 41, 1968, s. 105-129; L.J. Hume, Bentham and Bureaucracy, Cambridge 2003.

${ }^{13}$ Fryderyk August zgodził się np., aby członkowie rad departamentalnych i powiatowych „czasem i z grona nieszlachty obrani” zostawali. Sesja nr 221 z 19 XI 1808, w: Protokoły Rady Stanu Księstwa Warszawskiego, t. 1, cz. 2, wyd. B. Pawłowski, Toruń 1962, s. 242. W tym kontekście można również spojrzeć na prośbę Stanisława Wawrzeckiego, prezydenta Warszawy, o prawo noszenia mundurów obywatelskich (dla szlachty ziemiańskiej) przez członków rady miejskiej (również pochodzących z wyboru). Sesja nr 405 z 19 VIII 1809, w: Protokoły Rady Stanu Księstwa Warszawskiego, t. 2, cz. 2, wyd. B. Pawłowski, T. Mencel, Toruń 1968, s. 148-149.

${ }^{14}$ J. Czubaty, Wodzowie i politycy. Generalicja polska lat 1806-1815, Warszawa 1993, s. 224.

${ }^{15} \mathrm{Na}$ temat składu senatu (jak i całego sejmu) w tym czasie patrz: J. Skowronek, Skład społeczny i polityczny sejmów Księstwa Warszawskiego i Królestwa Polskiego, PH 52, 1961, 3, s. 466-494.

${ }^{16} \mathrm{Na} 1085$ sędziów pokoju zaledwie dwóch nie było pochodzenia szlacheckiego. A. Rosner, Sędziowie i urzędnicy sądów pokoju w Księstwie Warszawskim, PH, 79, 1988, 4, s. 667. 
wstaniu listopadowym, istotna jest sama świadomość nieodwracalnych zmian $^{17}$.

Do pewnego stopnia za pokrewne zjawisko należy uznawać fakt obejmowania czołowych stanowisk przez szlachtę bez „znamienitego” pochodzenia, majątku lub koneksji dawnego typu (np. Józef Wybicki, bracia Antoni i Onufry Wyczechowscy, Józef Kalasanty Szaniawski, Michał Woźnicki). Co prawda, spektakularne jednopokoleniowe kariery w stylu from rags to riches zdarzały się w poprzednich wiekach, a nawet stanowiły istotny motor rozwoju elity magnackiej ${ }^{18}$. Bezprecedensowa była jednak skala oraz charakter „warszawskiego" zjawiska - po raz pierwszy urząd administracyjny wiązał się przecież z tak bezpośrednim i sformalizowanym udziałem w faktycznej władzy.

Z punktu widzenia ówczesnej sytuacji społecznej zmiana relacji między szlachectwem a urzędem zasługuje na szczególną uwagę. Za czasów Rzeczypospolitej wszystkie urzędy były z definicji szlacheckie, a więc ich repartycja na szczeblu powiatowym, wojewódzkim bądź centralnym określała układ zależności w obrębie tej grupy społecznej ${ }^{19}$. Dziedziczny klejnot i osobista kariera publiczna definiowały społeczną kondycję każdego szlachcica, dopełnianą przez warunki majątkowe i zewnętrzną reprezentację statusu. Szlachectwo było więc kondycją par excellence publiczną. Natomiast w Księstwie choć własność ziemska i pochodzenie wciąż zachowały charakter szlacheckich przywilejów, to urząd już się do nich nie zaliczał. Oświeceniowy racjonalizm, stojący u podstaw nowoczesnego rozumienia skutecznej i merytorycznej biurokracji, wykluczał taką ewentualnośćc ${ }^{20}$.

Jednak wysoka społeczna ranga urzędu w gruncie rzeczy się nie zmieniła, głównie ze względu na jego polityczny charakter - administracja bynajmniej nie cierpiała na brak zainteresowania pracą w jej szeregach ze strony szlachetnie urodzonych. Zgłaszali się do niej zarówno młodzi,jak

${ }^{17}$ S. Węgrzecki, Przestrogi do utworzenia Królestwa Polskiego, 20 III 1813, BC, sygn. 5243, k. 127; patrz także: I. Rychlikowa, Ziemiaństwo polskie 1789-1864. Zróżnicowanie społeczne, Warszawa 1983, s. 233.

${ }^{18}$ Por.: T. Zielińska, Magnateria polska epoki saskiej. Funkcje urzędów i królewszczyzn w procesie przeobrażeń warstwy społecznej, Wrocław 1977.

${ }^{19}$ Ibidem, s. 114.

${ }^{20}$ Np. minister sprawiedliwości Feliks Łubieński, sam będący domorosłym prawnikiem, otaczał się urzędnikami mającymi odpowiednie doświadczenie, co nie znajdowało uznania w opinii szlacheckiej elity. J.U. Niemcewicz, op. cit., s. 30. W Księstwie wprowadzono również wymogi kwalifikacyjne dla urzędników: P. Cichoń, Kwalifikacje zawodowe urzędników jako podstawa kształtowania się systemu biurokratycznego $w$ Księstwie Warszawskim, w: Dzieje biurokracji na ziemiach polskich, red. A. Górak, I. Łuć, D. Magier, Lublin-Siedlce 2008, s. 133-147. Nawet jeśli nie zawsze ściśle stosowano się do tych reguł, przełomowe znaczenie miał już sam fakt ich ustanowienia. 
i starsi wiekiem, biedniejsi oraz bogatsi ziemianie ${ }^{21}$. Nawet dawni magnaci, pozbawieni tradycyjnych niedziedzicznych dostojeństw, starali się o nowe, aby podtrzymać społeczny autorytet własny oraz swoich potomków ${ }^{22}$. Tym bardziej dotyczyło to jednostek, które z różnych względów mogły się czuć niepewnie na swojej wysokiej pozycji, zawdzięczanej przedrozbiorowej karierze ${ }^{23}$. Natomiast kształtująca się biurokracja, tak jak we Francji, potrzebowała tradycyjnych elit do obsadzania wyższych stanowisk, aby uzyskać powszechną akceptację i niezbędny autorytet $^{24}$. Czasami, oprócz prestiżu czy faktycznej władzy, posada miała również stanowić istotne (jeśli nie podstawowe) źródło dochodu ${ }^{25}$.Jednak z drugiej strony nie brakowało też przypadków ostentacyjnej odmowy angażowania się w działalność nowych instytucji ${ }^{26}$.

W tym momencie, kiedy integralny związek szlachectwa i kondycji urzędniczej stawał się opcjonalny, ich drogi zaczęły się rozchodzić. Pod koniec 1815 r. Rajmund Rembieliński (wówczas jeszcze dość kontrowersyjny koryfeusz nowoczesności w „publicznym” środowisku) śmiało orzeknie na łamach opiniotwórczego „Pamiętnika Warszawskiego”, że „oświeconemi ludźmi zarządzać najznakomitszym jest zaszczytem rządów, gdyż te przeznaczeniu świata wsteczny bieg nadać, wedle prawideł zdrowego rozsądku zamiaru mieć nie mogą" ${ }^{27}$. Urząd, a więc w tamtych realiach realną władzę, chciano więc jednoznacznie uzależnić od indywidualnych predyspo-

${ }^{21}$ Patrz listy starających się o urzędy: AGAD, Rada Stanu i Rada Ministrów Księstwa Warszawskiego II/51; Rada Ministrów Księstwa Warszawskiego (dalej - RM) II/27; M. Handelsman, Pod znakiem Napoleona. Studia historyczne, Warszawa 1913, s. 210.

${ }^{22}$ Chociażby pobieżna lektura spisów najwyższych „warszawskich” dygnitarzy wskazuje na szerokie zainteresowanie oficjalną karierą wśród reprezentantów tego środowiska.

${ }^{23}$ Były wojewoda gnieźnieński Józef Radzimiński nie zamierzał odmawiać przyjęcia zaoferowanej mu funkcji senatora-kasztelana, choć ponoć boleśnie odczuł zniewagę. Jak zanotował ówczesny sekretarz Senatu: „ckliwie z początku przyjął tę poniżenia urazę, lecz później wolał poniżej znaczyć, niż godność tę odrzucić”, J.U. Niemcewicz, op. cit., s. 23-24.

${ }^{24}$ F. Łubieński, Pamiętnik, wyd. W. Chomętowski, Warszawa 1876, s. 193 (przypadek sędziów, podlegających ministrowi sprawiedliwości); patrz również: T. Mencel, Organizacja sądownictwa na ziemiach polskich w okresie Komisji Rządzacej (1807), PH 40,1949, s. 240.

${ }^{25}$ List Anny z Krajewskich Nakwaskiej do siostry Teresy Rastawieckiej, grudzień 1809, w: J. Falkowski, Obrazy z życia kilku ostatnich pokoleń w Polsce, Poznań 1884, s. 266; list Tomasza Łubieńskiego do żony Konstancji z Ossolińskich, 30 V 1812, w: R. Łubieński, Generał Tomasz Pomian Hrabia Łubieński, t. 1, Warszawa 1899, s. 236 (na temat jego siostry Pauliny Morawskiej).

${ }^{26}$ Patrz np.: W. Wężyk, Kronika rodzinna, Warszawa 1987, s. 129. Trudno obecnie określić skalę tego zjawiska.

${ }^{27}$ R. Rembieliński, Niektóre ogólne uwagi nad ekonomia polityczną i jej główną częścia finansami, ,Pamiętnik Warszawski” 1815, t. 3, nr 11, s. 326. 
zycji. Pokongresowa kontynuacja napoleońskich rozwiązań jeszcze bardziej ugruntowała te zmiany. Moim zdaniem, właśnie w tym procesie (obok, rzecz jasna, ewolucji systemu gospodarczego) należy doszukiwać się genezy specyficznego zjawiska społecznego, jakim było ziemiaństwo na ziemiach polskich przełomu XIX i XX w. - grupa bezpośrednio wywodząca się z przedrozbiorowej szlachty, lecz znacznie się od niej różniąca.

W tym kontekście nie można oczywiście zapomnieć o tradycyjnych, ścisłych personalnych związkach pomiędzy miejscową elitą edukacji i urodzenia ${ }^{28}$. Odpowiedzialni za kształt administracji państwowej zapewne z góry zakładali, że przeważająca część potencjalnych kandydatów na urzędy wywodzi się ze szlachty. Tymi okolicznościami można tłumaczyć wyjątkowy w skali Wielkiego Cesarstwa (nie wspominając o reszcie Europy) brak mechanizmów nobilitacyjnych, które umożliwiałyby skromniej urodzonym urzędnikom bądź wojskowym starać się o szlachectwo jako formę najwyższego wyróżnienia za służbę publiczną. W latach 1807-1815 pojęcie uszlachcenia za zasługi w ogóle nie funkcjonowało. Co prawda Fryderyk August nadał szlachectwo kilku obywatelom Księstwa, m.in. wspomnianemu Woydzie ${ }^{29}$. Czynił to jednak jako król saski, a nie książę warszawski, którego kompetencje w zakresie rozdawnictwa honorów ograniczały się do polityki orderowej. Najwidoczniej nowy system polityczny, który szczególnie nie dowartościowywał starego szlachectwa, nie potrzebował również nowego.

Zaniechanie nobilitacji, tak integralnie związanych ze staropolską kulturą szlachecką (i repartycją staropolskich urzędów - vide prawo scartabellatu $)^{30}$, mogło mieć również inny cel. Wszakże rozdzielność dziedzicznego przywileju od zasługi osobistej (opierającej się na służbie publicznej) została w ten sposób zdecydowanie dobitniej podkreślona. Być może podobne intencje kryły się za zastanawiającym brakiem „warszawskich” tytułów dziedzicznych. Wszakże takowe nadawano we wszystkich napoleońskich monarchiach, z mikroskopijnym księstwem Neuchâtel włącznie. Tytuł stanowił istotne narzędzie obłaskawiania elit przez scentralizowany aparat władzy ${ }^{31}$. Pod tym względem nie powinno się raczej spodziewać

${ }^{28}$ Szerzej na ten temat patrz w: M. Janowski, Narodziny inteligencji 1750-1831, Warszawa 2008; W. Rostocki, Korpus $w$ gęsie pióra uzbrojony. Urzędnicy warszawscy $w$ latach 1807-1831, Warszawa 1972.

${ }^{29}$ Szlachta wylegitymowana w Królestwie Polskim w latach 1836-1861, oprac. E. Sęczys, Warszawa 2000, s. 775; Polska encyklopedia szlachecka, oprac. S. J. Starykoń-Kasprzycki, M. Dmowski, t. 9, Warszawa 1938, s. 184.

${ }^{30}$ Zgodnie z wielowiekową tradycją, świeżo nobilitowani, jak również ich synowie oraz wnuki, nie mogli dzierżyć urzędów szlacheckich. W szczególnych przypadkach można było uzyskać uwolnienie od tej zasady.

${ }^{31} \mathrm{~J}$. Tulard, op. cit., passim. 
oporów po stronie polskiej. Sam Napoleon wykreował wśród Polaków jednego hrabiego i kilku baronów Cesarstwa, a na poziomie kontaktów towarzyskich tytuły od dawna zyskały sobie prawo obywatelstwa ${ }^{32}$. Warto przypomnieć, że trzech członków Komisji Rządzącej (Stanisław Kostka Potocki, Franciszek Ksawery Działyński, Piotr Bieliński) kontrasygnowało Konstytucję 1807 r. jako hrabiowie. Wkrótce problem niekontrolowanego rozpowszechnienia się tego chronionego prawem przywileju musiał rozwiązać Aleksander I, przeprowadzając surową weryfikację. W jej efekcie kilkudziesięciu obywateli Królestwa (oraz innych ziem dawnej Rzeczypospolitej) uzyskało status certyfikowanego „polskiego” księcia, hrabiego bądź barona. Co znamienne, w znacznej mierze byli to funkcjonariusze aparatu władzy ${ }^{33}$.

W tym kontekście nie można również zapomnieć o różnicy w pozycji urzędników publicznych przed rozbiorami i po nich. Objawiająca się w tym czasie potęga administracji musiała być autentycznym szokiem dla ludzi pokroju Dominika Kuczyńskiego (1760-1819), czy Kajetana Koźmiana (1771-1856) ${ }^{34}$, bodaj najbardziej znanych malkontentów, dobrze pamiętających czasy przedrozbiorowe. Czarny mit Rady Nieustającej, który tak bardzo działał na wyobraźnię stanisławowskich polityków ${ }^{35}$, stał się teraz całkiem realną rzeczywistością. Niemal wszystkie publiczne dostojeństwa straciły swój honorowy charakter, często związany z reprezentowaniem interesów współobywateli. Wiele staropolskich urzędów wyższego szczebla było przecież obieralnych, a senatorstwo również ostatecznie stało się takim ${ }^{36}$. Po roku 1807 urzędnik był natomiast przedstawicielem autentycznego aparatu przemocy, mającego środki, aby bo-

${ }^{32}$ Co więcej, niektórzy, korzystając z faktu „odrodzenia” polskiej państwowości, zamierzali nawet prosić Fryderyka Augusta o tego typu zaszczyt. Ordynatowi pińczowskiemu margrabiemu Józefowi Wielopolskiemu (ojcu Aleksandra) marzył się wówczas tytuł książęcy. A.M. Skałkowski, Aleksander Wielopolski w świetle archiwów rodzinnych (1803-1877), t. 1, Poznań 1947, s. 33.

${ }^{33}$ AGAD, Akta Heroldii Królestwa Polskiego 1-5 (materiały dotyczące przedlistopadowej legitymacji tytułów). Wzgląd na służbę państwową kandydatów charakteryzował ówczesną politykę nobilitacyjną: M. Getka-Kenig, Nobilitacje i nobilitowani w Królestwie Polskim w latach 1816-1830 - próba charakterystyki, PH, 100, 2009, 4, s. 725-754.

${ }^{34} \mathrm{Na}$ temat poglądów społeczno-politycznych Kuczyńskiego w: Listy Dominika Kuczyńskiego do barona Goswina de Stassarta z lat 1807-1809, red. W. Zajewski, B. Cygler, Gdańsk 2002; o Koźmianie patrz: M. Mycielski, „Miasto ma mieszkańców, wieś obywateli”. Kajetana Koźmiana koncepcje wspólnoty politycznej (do 1830 roku), Wrocław 2004.

35 Por: J. Michalski, Opozycja magnacka i jej cele w początkach Sejmu Czteroletniego, w: idem, Studia historyczne z XVIII i XIX wieku, t. 1: Polityka i społeczeństwo, Warszawa 2007, s. 285-304.

${ }^{36}$ Szerzej na ten temat patrz: Z. Góralski, Urzędy i godności w dawnej Polsce, Warszawa 1988. 
leśnie egzekwować swoje decyzje wbrew opiniom „prywatnych” obywateli ${ }^{37}$. Zachowano co prawda skromną pulę urzędów obieralnych, jednak ich tradycyjny prestiż wyraźnie bladł w zestawieniu z autentyczną mocą sprawczą funkcji administracyjnych ${ }^{38}$.

Last but not least, napoleoński centralizm wprowadził nad Wisłą jeszcze jedną innowację, która, wydaje się, miała kluczowe znaczenie dla ówczesnego pojęcia elity - miarą prestiżu stał się stopień zależności od jednoznacznego, naczelnego źródła władzy politycznej, jakim był monarcha. Pomimo wytężonych starań regalistycznej propagandy końca XVIII w., pozostającej na usługach dworu warszawskiego, do końca istnienia Rzeczypospolitej król jako czynnik polityczny (jeden z trzech stanów sejmujących) cieszył się co najmniej kontrowersyjną opinią w szerokich masach "narodu” szlacheckiego ${ }^{39}$. Umiarkowany monarchizm współtworzonej przez Stanisława Augusta Konstytucji 3 Maja stanowi tego znakomity dowód.

Co prawda, pierwsze lata zaborów mogły w pewnym stopniu przysposobić rodzime elity do funkcjonowania w społecznych realiach państwa absolutystycznego, jednak sytuacja, jaka nastała w 1807 r., nadała relacji poddani-król całkiem nowego charakteru. Od tej pory monarcha stał się nie tylko niepodważalnym zwierzchnikiem aparatu politycznego, ale przede wszystkim gwarantem państwowości. „Odrodzona” przez zewnętrznego „wskrzesiciela” Polska mogła istnieć wyłącznie jako monarchia - przez cały okres 1807-1830 tak powszechna jeszcze niedawno retoryka republikańska nie miała większej racji bytu. Tym samym ci, którzy znajdowali się najbliżej majestatu i byli mu najbardziej posłuszni, odgrywali czołową rolę w hierarchii dostojeństw. Rzecz jasna, staropolska podejrzliwość wobec ministrów i innych „dworaków" bynajmniej nie wygasła i składała się na generalną krytykę centralistycznego systemu. Jednak w porównaniu z sytuacją przedrozbiorową, kiedy opcja regalistyczna pozostawała w nieustannej defensywie, układ sił w napoleońskiej Polsce (de iure z Fryderykiem Augustem, de facto z samym Napoleonem) prezentował się raczej odwrotnie, a sam król, niczym w nowoczesnej monarchii konstytucyjnej, pozostawał poza polem rażenia opozycyjnej krytyki. Wydaje się, że podobny atak

${ }^{37}$ Klasycznym urzędniczym antybohaterem tego pokolenia stał się R. Rembieliński. H.S. Michalak, Działalność Rajmunda Rembielińskiego w oczach współczesnych i potomnych, w: Rajmund Rembieliński. Jego czasy i jego współcześni, red. A. Barszczewska-Krupa, Warszawa 1989, s. 107-126.

${ }^{38}$ Dobrym tego przykładem są problemy z obsadzeniem stanowisk sędziów pokoju.

${ }^{39}$ A. Grześkowiak-Krwawicz, Regina libertas. Wolność w polskiej myśli politycznej XVIII wieku, Gdańsk 2006, s. 189-214. 
godziłby w podstawy samego „odrodzenia” (a nie jedynie takiej lub innej formy prawnoustrojowej), czego raczej nikt w ówczesnej sytuacji sobie nie życzył.

Tak jak we Francji, zaadaptowany nad Wisłą model służby państwowej wymagał odpowiedniej struktury hierarchicznej. Jej praktyczne znaczenie właściwie dotyczyło jedynie oficjalnych uroczystości, zwłaszcza tych najwyższego szczebla z udziałem króla lub przewodniczących organów konstytucyjnych. Dawały one bowiem jedyną okazję do zebrania się w tym samym miejscu i czasie przeróżnych funkcjonariuszy państwowych. Tych z kolei należało uporządkować zgodnie z wymogami ceremonialnych procesji, najbardziej efektownego (i symbolicznie ważkiego) przejawu obecności władzy politycznej w przestrzeni publicznej. Równocześnie, poprzez determinację zewnętrznych form reprezentacji, precedencja miała w założeniu określać hierarchię prestiżu, a więc odzwierciedlać (a nawet kształtować) powszechną opinię o znaczeniu poszczególnych stanowisk. Stąd waga, jaką w tym czasie przykładano do kwestii mundurów (uniformów) i ich różnorodności, odpowiadającej hierarchii stanowisk ${ }^{40}$.

Rada Ministrów Księstwa Warszawskiego zdała sobie sprawę z potrzeby zaprowadzenia precedencji w dość prozaicznych okolicznościach. 28 maja 1808 r. wpłynęła do niej dyspozycja Fryderyka Augusta w sprawie ustanowienia opłat od obejmowania funkcji urzędowych ${ }^{41}$. W odpowiedzi przesłała zawiadomienie,,,iż nie może być przez nią ułożona taryfa osobna stempla a osobna jurium cancellaria pokąd" król nie zadeklaruje,,,jakie urzędy wyższymi, które niższymi [- - ] postanowić zamyśla" ${ }^{42}$. Dekretem z 14 lipca 1808 r. władca polecił więc zastosować się do tradycyjnego „stopniowania w Królestwie Polskim używanego [- - ] to jest naprzód senatorów, potem ministrów, po niej konsyliarzów Rady, dalej urzędy oddzielnych Władz od Nas postanowionych Rządowych i Administracyjnych" ${ }^{43}$. Nie wiadomo, na jakiej podstawie ustalono tak ścisłą, rzekomo historyczną hierarchię. Być może doradzał w tej kwestii stale obecny przy boku królewskim minister Stanisław Breza. Ze względu na bliskie związki między Saksonią i Rzecząpospolitą w poprzednim stuleciu, sam Fryderyk August mógł mieć również pewne wyobrażenie na ten temat. W każdym razie tym, co wydaje się szczególnie interesujące w treści tego postanowienia (bo brzemienne w skutki), jest jednoznaczne ustalenie wyższości senatorów nad ministrami.

${ }^{40}$ Szkic projektu do dekretu o mundurach obywatelskich, AGAD, RM II/9, k. 1-10; projekt do dekretu, Archiwum Publiczne Potockich, 143 (dalej: APP), s. 236-250.

${ }^{41}$ Wypis z protokołu Sekretariatu Stanu z 9 V 1808, AGAD, RM II/30, k. 1-1v.

${ }^{42}$ Wypis z protokołu Sekretariatu Stanu z 14 VII 1808, ibidem, k. 2 (król odniósł się do opinii Rady w swoim piśmie).

${ }^{43}$ Wypis z protokołu Sekretariatu Stanu z 14 VII 1808, ibidem, k. 2-3. 
Zapewne zdawano sobie sprawę, że przyjęty porządek nie będzie miał praktycznego zastosowania ze względu na swoją schematyczność. Dlatego w ciągu kilku miesięcy opracowano pierwszy projekt oryginalnej „warszawskiej" precedencji. W liście do króla z 12 listopada 1808 r. zaznaczono, że organizacja administracji nie została jeszcze zakończona, dlatego ewentualne korekty w jej treści będą prawdopodobnie nieuniknione ${ }^{44}$. Projekt nosi datę 11 listopada i określa następującą kolejność na najwyższym szczeblu: prezes Senatu, prezes Rady Stanu i Ministrów, senatorowie. Dopiero dalej idą ministrowie oraz radcy stanu. Czyniąc ukłon w stronę przedrozbiorowych tradycji parlamentarnych, na okres sejmu przewidziano charakterystyczną modyfikację. Przed senatorami, a tuż za prezesem obu Rad stać miał każdorazowy marszałek Izby Poselskiej, podczas gdy aktualnych posłów porównano $\mathrm{z}$ radcami stanu. Natomiast tak między senatorami, jak i wszystkimi pozostałymi urzędnikami tej samej rangi kolejność miała być ustalana na podstawie daty nominacji ${ }^{45}$.

Można się domyślać, że ze względu na wciąż postępującą organizację urzędów projekt ostatecznie nie wszedł w życie i na pewien czas jakby o nim zapomniano. Z przyczyn praktycznych jakaś forma precedencji funkcjonowała i tak, zapewne według wspomnianych wskazówek króla z 14 lipca 1808 r. Nie można było przecież zrezygnować z różnego rodzaju uroczystości, które wymagały obecności najwyższych urzędników (w tym audiencji u króla na Zamku). Zapewne starano się także interpretować pod tym kątem zapisy Konstytucji. Na jakiejś podstawie musiała również powstać kolejność „magistratur generalnych”, stosowana w kalendarzykach politycznych. Warto też wspomnieć o notatce z 1809 r., sporządzonej przez Stanisława Kostkę Zamoyskiego, prezesa rządu galicyjskiego, który wypisał porządek urzędów w Księstwie. W jego szkicu Senat zajmował pierwszą pozycję, tuż za nim Rada Stanu ${ }^{46}$. Z jakiego źródła ordynat czerpał swoją wiedzę, nie wiadomo. Możliwe nawet, że kierował się prywatnymi wyobrażeniami na ten temat.

Sprawa ponownie pojawiła się na obradach Rady w kwietniu 1810 r. Bezpośrednim powodem mogła być reorganizacja administracji państwowej po przyłączeniu Galicji Zachodniej. Abstrahując od niemal identycznego wstępu, nowy projekt znacznie odbiegał od poprzedniej koncepcji ${ }^{47}$.

${ }^{44}$ List prezesa Rady Ministrów Ludwika Gutakowskiego do króla z 12 XI 1808,ibidem, k. 4.

${ }^{45}$ Projekt dekretu królewskiego, ibidem, k. 5-6v.

${ }^{46}$ Notatka Stanisława Kostki Zamoyskiego na temat ustroju Księstwa, AGAD, Archiwum Zamoyskich 82, s. 117-118.

${ }^{47}$ Projekt dekretu królewskiego, AGAD, RM II/30, k. 7-10v. Data ustalona na podstawie zachowanego brudnopisu: ibidem, k. 27-31v. 
Kolejność pierwszych czterech dostojeństw prezentowała się następująco: 1) prezes Senatu lub prezes Rady Ministrów i Stanu, 2) byli komisarze rządzący, 3) ministrowie, 4) senatorowie. Łatwo dostrzegalne poniżenie Senatu nie było jednak całkowite. Należy bowiem pamiętać, że wszyscy członkowie dawnej Komisji Rządzącej pełnili funkcje senatorskie, stanowiąc przeszło połowę ówczesnego składu Senatu.

Uwzględnienie honorowych praw komisarzy mogło uchodzić za logiczne posunięcie. W chwili budowania zrębów warszawskiej państwowości to właśnie oni formowali jedyny centralny ośrodek władzy, dysponujący kompetencjami ustawodawczymi oraz wykonawczymi, przekraczającymi znacznie formalne uprawnienia późniejszego księcia warszawskiego. Z pozoru to hierarchiczne wywyższenie nie miało nic wspólnego $\mathrm{z}$ ich aktualnym senatorstwem. Jednak fakt, że to komisarze stanowili rdzeń oryginalnego składu Senatu, ważył na znaczeniu całej instytucji i dalszych decyzjach w przedmiocie nominacji - w kolejnych latach prestiż Senatu zależał w znacznej mierze od doboru oryginalnego składu. Nie chodziło tu oczywiście o faktyczne wpływy, ale o siłę autorytetu, jakim rozporządzało siedmiu „ojców” warszawskiej państwowości ${ }^{48}$.

Ponadto warto zwrócić uwagę na fakt, że w określonych sytuacjach bezwzględne pierwszeństwo przynależało prezesowi Senatu. Warunek stanowiła obecność monarchy. W razie jego absencji na tej pozycji występował prezes obu Rad. Natomiast w sytuacji, gdy „władze in corpore przytomne” miały być „obchodom lub uroczystościom” oficjalnym, wypadało Senatowi przeznaczyć nadrzędne miejsce, na czele wszystkich urzędów. Dopiero w dalszej kolejności miała iść Rada Stanu, Główna Izba Obrachunkowa, Sąd Apelacyjny itd. Tymczasowo zwoływana Izba Poselska równa była rangą Radzie Stanu, z którą w gruncie rzeczy tworzyła w trakcie sejmu jedno ciało.

Wciążjednak brakowało konkretnych rezultatów, gdyż omówiony projekt nie wszedł w życie. Sprawa odwlekła się do 24 sierpnia kolejnego roku. Co bezpośrednio skłoniło wówczas członków Rady Ministrów do zajęcia się tą niewyjaśnioną kwestią, nie wiadomo. Być może była to własna inicjatywa

${ }^{48}$ O symbolicznym znaczeniu, jakie społeczeństwo Księstwa Warszawskiego przypisywało działalności komisarzy (pomimo otwartej krytyki ich miernych kompetencji administracyjnych), może świadczyć uwaga proboszcza katedry warszawskiej Adama Prażmowskiego w kazaniu pogrzebowym prezesa Senatu Ludwika Gutakowskiego: „Nie chciał Napoleon Wielki odwlekać uiszczenia powszechnych nadziei. Powołał mężów miłością dobra publicznego zajętych, oświeceniem i cnotą znakomitych, złożył w ich ręku najwyższą kraju władzę i powierzył im dzieło odnowienia zatartych śladów ojczystych [podkreślenie moje-M.G.-K.]". Cyt. z: A.M. Prażmowski, Kazanie na pogrzebie Jaśnie Wielmożnego Ludwika Gutakowskiego wojewody, prezesa Senatu Księstwa Warszawskiego, Warszawa [1811], s. 9. 
ministra policji Aleksandra Potockiego, który przedłożył wtedy pismo poświęcone problemom z ustaleniem urzędowej hierarchii podczas uroczystości państwowych ${ }^{49}$. Po raz pierwszy poddano to zagadnienie dogłębnej analizie, co zapewne wynikało z dotychczasowych doświadczeń. Na samym początku minister ujawnił przesłanki, które jego zdaniem powinny decydować o wyznaczeniu ścisłej precedencji urzędów. Trudno się dziwić, że przede wszystkim odwołał się do prawnie ustalonych kompetencji poszczególnych stanowisk oraz wynikających z nich zależności hierarchicznych.Jego zdaniem „stopień urzędu gdzie go prawo wskazuje”, powinien być dodatkowo zweryfikowany przez „opinię pierwszeństwa przyjętą w publiczności”. Minister nie zapomniał równocześnie o „zwyczajach do których Naród był przywykły".

W myśl przywoływanego sprawozdania precedencja nie mogła być wyłącznie urzędowym ,stopniowaniem”, zdeterminowanym rozdziałem władzy w ramach podyktowanych konstytucją i dekretami. Stanowiąc podporę autorytetu władzy, nie powinna niczego narzucać ani kreować nowej jakości w oderwaniu od opinii społeczeństwa. Jej celem było odpowiadanie na powszechne oczekiwania i poglądy. Zdawano sobie sprawę, że nie zawsze były one zgodne z intencjami prawodawcy, odpowiedzialnego za prestiż państwa, czyli jego instytucji. W przeciwnym razie szukanie konsensusu okazywałoby się zbędne.

Z oczywistych względów podstawą musiały być współczesne rozwiązania w duchu napoleońskim. One oferowały gotowe wzorce, które potem można było dostosowywać do miejscowych warunków, oszczędzając sobie czasu i trudu w razie pracy nad oryginalnym projektem. Potrzeba ustalenia precedencji wynikała również z logiki scentralizowanego systemu francuskiego - jego afirmacja nie mogła się bez niej obyć. „Zbliżenie Konstytucji nam nadanej do Konstytucji francuskiej” w sposób naturalny skłaniało do szukania inspiracji nad Sekwaną. Dlatego minister Potocki proponował odwołać się do dekretu z 12 messidora roku XII (23 VI 1804), zaprowadzającego precedencję w Cesarstwie. Niektóre modyfikacje, mające nadać nowym przepisom „narodowy” charakter, były oczywiście nieuniknione. $Z$ tego względu przynajmniej "dawne ceremoniały polskie powinny by być wzięte na uwage". Minister, znany ze swojego sceptycyzmu wobec nowych porządków ${ }^{50}$, zapewne szczerze pragnął znaleźć w nich wzorzec dla opracowywanego

${ }^{49}$ Pismo ministra policji Aleksandra Potockiego z 23 VIII 1811, AGAD, RM II/30, k. $17-18 \mathrm{v}$.

${ }^{50}$ Jego poglądy miały ponoć istotny wpływ na dymisję $\mathrm{z}$ funkcji ministra na jesieni 1811 r. B. Grochulska, Potocki Aleksander h. Pilawa (1756-1812), PSB, t. 27, Wrocław 1983, s. 756. 
projektu. „Przejrzawszy akta marszałkowskie”, rozczarowany zorientował się jednak, że „nic takiego co by do teraźniejszego przypadku przystosowanym było", nie dało się w nich znaleźć.

Opisana sytuacja pozwala zrozumieć, jak rewolucyjne zmiany zaszły w ciągu tamtych lat. Mimo wszelkich pragnień i usiłowań „Warszawian” bezpowrotnie odcinały one napoleońską Polskę od Rzeczypospolitej Obojga Narodów. Poszukiwanie wzajemnych analogii między jedną a drugą rzeczywistością wynikało $\mathrm{w}$ tym przypadku $\mathrm{z}$ daleko posuniętego ahistoryz$\mathrm{mu}$, chyba w znacznym stopniu nieuświadomionego. Pozwalał on łudzić się wizją bezpośredniej kontynuacji, będącej niczym więcej jak mitem, wokół którego starano się kształtować współczesną świadomość państwowo-narodową. Konfrontacja z tym faktem nie pozwalała uczynić nic innego jak: „zostać [- ] przy ceremoniale francuskim" 51 i przeszczepić obcą normę na własny grunt.

Rzecz jasna, stopień napoleonizacji (lub jak kto woli, modernizacji) nie zaszedł tak daleko, aby można było tę operację przeprowadzić bezboleśnie. Potocki był świadom problemów na poziomie różnic historyczno-kulturowych, nie tak szybko poddających się odgórnej regulacji. Ideał państwa nie współgrał w tym przypadku z miejscowymi realiami. Jak podkreślał, prawo francuskie zastrzegało, że „Senat, Rada Stanu [- - ] Ciało prawodawcze, Trybunat, Sąd Kasacyjny, mieć nie mogą ani rangi ani miejsca sobie oznaczonego w czasie obchodów uroczystych, chyba, że wyrażonym listem cesarskim [- - ] do tego aktu powołanymi zostaną". Z tym wiązała się kwestia ceremoniału „przy obchodach kościelnych”, podczas których we Francji „każda respective władza oddzielnie udaje się na miejsce uroczystości”. W Księstwie natomiast „prawie wszystkie Nasze obchody są kościelne”, dlatego „naśladowanie takiego przykładu zostawiałoby wiele trudności". Wymóg osobistego zaangażowania monarchy miał ścisły związek z kłopotliwą kwestią jego „przytomności” w sytuacji notorycznego „oddalenia się” z Warszawy. Ta z kolei pociągała za sobą „konieczność by niejakiej osobie lub władzy nadana była reprezentacja” substytuująca nieobecny majestat.

Abstrahując od jakichkolwiek odwołań staropolskich, już same podstawy nadwiślańskiego systemu uniemożliwiały proste odwzorowanie modelu francuskiego nawet $w$ tak z pozoru nieskomplikowanej kwestii jak precedencja. Dlatego ustalenie, komu należy się pierwszeństwo pod nieobecność głowy państwa. stało się podstawą całego opisywanego projektu autorstwa Potockiego: ,,jeżeli ten pierwszy stopień oznaczonym nie zostanie w dalszym postępowaniu trudno trafić do porządnego końca, trudniej jeszcze

${ }^{51}$ Pismo ministra policji z 23 VIII 1811, AGAD, RM II/30, k. 17v. 
oznaczyć honory stosownie do stopnia oddawać się mające" 52 . Co prawda, „Najjaśniejszy Pan” delegował prezesa Rady Stanu, w której skład wchodzili ministrowie, odpowiedzialni za poszczególne gałęzie administracji rządowej, „lecz żadnej reprezentacyjnej nie udzielił [mu] władzy” (mowa tu rzecz jasna o reprezentacji władzy królewskiej).,,Jedynka” na liście pozostawiała tym samym pole do swobodnej interpretacji, wychodzącej poza treść Konstytucji.Zdaniem Potockiego, ambiwalentna pozycja prezesa „zapewne staje się powodem być mylnego tłumaczenia, bądź nieporozumień i błędów", które dotąd niepokoiły elitę władzy w Księstwie.

Po zaprezentowaniu swojego zdania na ten temat, tego samego dnia Rada Ministrów zleciła Potockiemu opracowanie projektu, który został jej przedłożony tydzień później, 2 września. Minister sam przyznał, że „starał się stosować go do konstytucji”, co jak widać, musiało sprawiać problemy. Nawiązując do zeszłorocznego projektu, Potocki zachował wymienne pierwszeństwo dla prezesów Senatu oraz Rady ministrów i Stanu, z kolei na trzeciej pozycji umieścił ministrów, a na czwartej senatorów. Różnica polegała jednak na wykluczeniu komisarzy rządzących z całej listy, aby na ich miejsce wstawić arcybiskupa gnieźnieńskiego (nota bene z urzędu zasiadającego w Senacie). W ten sposób nadawano „warszawskiej” precedencji bardziej francuski charakter. Według ministra specyficzna funkcja tego hierarchy jako legata „a latere" upodabniała go w pewnym stopniu do kardynałów. Tych ostatnich w Księstwie nie było, podczas gdy nad Sekwaną stanowili istotny element dworsko-dygnitarskiego środowiska ${ }^{53}$.

Projekt Potockiego spotkał się z krytyczną merytoryczną oceną księcia Józefa Poniatowskiego, który przedstawił swoje pisemne uwagi 18 października ${ }^{54}$. Zdaniem ministra wojny, ,projekt JW. Ministra Policji nie zdaje się dosyć dokładny, ponieważ obejmuje tylko stopniowanie urzędników, nie zaś władz w ciało zebranych", trudne do pogodzenia w sytuacji, kiedy najwyższe organy warszawskiej władzy państwowej składały się z instytucji kolegialnych. Dotyczyło to szczególnie Senatu i Rady Stanu, ,które razem zebrane, wysoki stopień mieć powinny, a których członki osobiście żadnego stopnia mieć nie mogą [- ] najpierwsze

${ }^{52} \mathrm{~W}$ podobnym duchu pisał Stanisław Małachowski w swoim projekcie na temat reformy Senatu z 1808 r.: „najniższa magistratura umieszczona w składzie całości Konstytucji Krajowej dla porządku działania ogółu ma swoją organizację, Se n at pias tujący najpierwsze przy tronie dostojeństwo [podkreślenie moje-M.G.-K.] być bez niej nie może". BC, 5216 IV, k. 337-339.

${ }^{53}$ AGAD, RM II/30, k. 20-21v. Por. także: AGAD, APP 143, k. 203-207.

${ }^{54}$ Uwagi ministra wojny, Józefa Poniatowskiego, dotyczące projektu ministra policji, AGAD, RM II/30, k. 22-24v. 
miejsce w porządku stopniowania zajmują, kiedy senator albo radca stanu osobiście do żadnego rzędu nie wchodzi”. Podobnie jak Potocki, książę widział w ceremoniale Cesarstwa najbardziej odpowiedni wzorzec do zastosowania, ,ponieważ konstytucją francuską [podkreślenie moje - M.G.-K.] się rządzimy i po większej części takich samych jak we Francji mamy urzędników". Jego zdaniem teza ministra policji, jakoby wzorcowa precedencja, hierarchizując urzędników, nie ustalała porządku urzędów, była bezpodstawna. Rzeczywiście sam dekret milczał na ten temat, ale, jak dowodził Poniatowski, najwyraźniej lepiej zorientowany w zasadach ustroju francuskiego, ,we wszystkich opisaniach [- - ] obrzędów zdarzonych we Francji, oczywiście pokazuje się pod rozdziałem o ceremoniach publicznych że stopniowanie ciał jest następujące: Ministrowie, Senat, Rada Stanu, Ciało Prawodawcze, Trybunat, Sąd Kasacyjny i Izba Obrachunkowa”. Inaczej być nie może, albowiem w „stopniowaniu [- - ] osobistym myśl prawodawcy wyraźnie okazuje", że miejsce w hierarchii należy się tylko tym urzędnikom, „którzy czynnie w jakiekolwiek części rządowej urzędują”, a więc senatorom w ich „senatoriatach" 55 , radcom stanu oddelegowanym do konkretnych zajęć administracyjnych (,,jest oddzielnym czynem zatrudniony"), a nawet generałom dowodzącym konkretnymi jednostkami, odpowiadającymi ich szarży i stacjonującymi w danym okręgu. Pozostali, a więc każdy inny członek Senatu czy Rady Stanu, poza tytułem, „żadnej nie ma rangi”. W Księstwie natomiast „senatoriatów nie ma”, więc "Senat tylko w ciało zgromadzony miejsce w stopniowaniu mieć może". Jego zdaniem, jedynym senatorem mogącym odpowiadać francuskiemu „senatorowi w swoim Senatoriacie” mógł być tylko prezes Senatu. W przeciwnym razie, gdyby utrzymano wyłącznie „stopniowanie osobiste", senatorowie i pozostali dostojnicy o analogicznym charakterze znaleźliby się w dość absurdalnej sytuacji. Wyrzucono by ich poza nawias precedencji, której celem było przecież odzwierciedlanie urzędowego prestiżu, którego nikt nie mógł im odmówić.

Przy tej okazji książę zaproponował własny projekt, uwzględniający obie oddzielne hierarchie. W przypadku „ciał” Senat miał postępować na drugim miejscu, po Radzie Ministrów, a przed Radą Stanu, w tym wypadku złożoną z samych radców. Natomiast według stopni „osobistych” senatorowie nie zostali uwzględnieni, poza prezesem, któremu przeznaczono miejsce dopiero po Prezesie Rady i ministrach, a przed radcami stanu

${ }^{55}$ Senatoriaty (les sénatoreries) - duże kompleksy dóbr ziemskich (jeden na każdy okręg apelacyjny) przekazywane przez Napoleona wybranym senatorom w dożywotnie użytkowanie (w charakterze dygnitarskich apanaży). 
będącymi zarazem dyrektorami poszczególnych wydziałów w ministerstwach. Duchowni senatorowie zostali wydzieleni z grona Senatu i mieli iść jeszcze dalej - arcybiskup na siódmej pozycji, a biskupi (gremialnie, bez rozróżnienia na diecezjalnych oraz pomocniczych, czyli niewchodzących do Senatu) na jedenastej, o trzy miejsca za prefektami. Ponadto Poniatowski przewidział jeszcze porządek ceremonialnego „konwoju”, kiedy obecne były zarówno „ciała”, jak i indywidualni urzędnicy. „Różnica między stopniowaniem” obu rodzajów „przymusza [- - ] prezesów od ciał oddzielić, gdyż albo prezesów zniżyć, albo ciało wywyższyć by trzeba". W takich przypadkach senatorowie mieli iść po radcach-dyrektorach, ustalając porządek między sobą według daty nominacji.

Warto przy tej okazji wspomnieć także o innych kontrowersjach, wynikających z nakładania się tradycji staropolskiej na model francuski, dobrze oddających atmosferę. w jakiej przyszło zastanawiać się nad honorowym wyróżnieniem senatorów. Projekt z 1810 r. przewidywał hierarchiczną roszadę w stosunku do sekretarza izby senatorskiej ${ }^{56}$, który według koncepcji z 1808 r. miał zajmować dość odległą trzynastą pozycję. Awansował bowiem aż na szóste miejsce, tuż po radcach stanu, a ponad generałami dywizji. Wywołało to sprzeciw Poniatowskiego, który tym razem wystąpił jako obrońca dziedzictwa przodków, nie odwołując się do żadnych „nowoczesnych" argumentów. Zadeklarował, że nie rozumie, dlaczego tak bardzo wyróżnia się urząd kompletnie nieznany w Rzeczypospolitej, podczas gdy dawniej generałowie lejtnanci (dowodzący dywizjami) mieli „miejsce swoje między urzędnikami koronnymi" ${ }^{57}$. Zabrania głosu przez księcia w tej sprawie wymagał interes armii, a zatem i ministerstwa wojny. W $1811 \mathrm{r}$. Potocki przewidział dla sekretarza Senatu dopiero szesnastą pozycję. Ponownie zabierający głos w tej sprawie Poniatowski wówczas w ogóle nie uwzględnił tego urzędu w swojej alternatywnym projekcie.

Także na niższym szczeblu, gdy w grę wchodziły urzędy o staropolskiej (przynajmniej z nazwy) metryce, kontrowersji nie brakowało. Problemów nastręczała chociażby pozycja prefektów. W czasie jednego z posiedzeń Rady Stanu zastanawiano się, czy honorowe miejsce na czele departamentu należało się im, czy może prezesom trybunałów cywilnych, tym ostatnim zapewne ze względu na luźną analogię z urzędem podkomorzego ${ }^{58}$. Przy okazji innej dyskusji padło z kolei pytanie o precedencję prefektów w skali całego kraju. Tym razem nie wiedziano, czy ustawić ich przed

${ }^{56}$ Przez cały omawiany okres był nim Julian Ursyn Niemcewicz, cieszący się powszechnym autorytetem.

${ }^{57}$ Pismo mnistra wojny Józefa Poniatowskiego do Rady Ministrów z października 1810 r., AGAD, RM II/30, k. 11v.

${ }^{58}$ Sesja 165 z 14 X 1808, w: Protokoły Rady Stanu, t. 1, cz. 2, s. 200. 
referendarzami, czy po nich. Za tymi pierwszymi przemawiać miał wzgląd na autorytet administracji państwowej. Jednak opowiadający się po stronie referendarzy odwoływali się do przeszłości, kiedy ci byli dygnitarzami koronnymi, spośród których wybierano sekretarza Rady Nieustającej. Ostatecznie przeważyły jednak względy praktyczne i interes administracji rządowej. Palma pierwszeństwa powędrowała więc w prefekturalne ręce ${ }^{59}$.

W kontekście opisywanej na początku „rewolucyjnej” zmiany charakteru służby publicznej ewidentny problem z ustaleniem pierwszeństwa między senatorami a ministrami można dość łatwo wytłumaczyć. Mamy wszakże do czynienia z dwoma kategoriami stanowisk (senatorstwem i ministerstwem), które w świadomości współczesnych należały do tradycji Rzeczypospolitej. Stanowiły one jeden z tych fundamentalnych elementów struktury państwowej, które podtrzymywały wiarę w „polskość” Księstwa, a więc pozwalały widzieć w nim odrodzone państwo polskie, chociażby $\mathrm{w}$ jego kadłubowej formie ${ }^{60}$. Ponadto były to stanowiska o tradycyjnie pokrewnym charakterze. Co więcej, staropolscy ministrowie wchodzili z urzędu w skład Senatu. Przez wieki w ramach senatorskiej hierarchii zajmowali ostatnią pozycję, jednak w epoce stanisławowskiej, w wyniku oświeceniowej racjonalizacji struktur politycznych, awansowali na drugą lokatę, tuż za wojewodami. Co znamienne (i ważne przy badaniach nad prestiżem), wzmocnienie ich rangi politycznej przejawiało się w roszadzie w ramach samej izby, a nie poprzez utworzenie niezależnego gremium. Również Konstytucja 3 Maja, która wprowadzała instytucję właściwej rady ministrów, za jaką jedynie po części można uznać wcześniejszą Radę Nieustającą, wciąż przewidywała, że ministrowie z urzędu mieli być członkami Senatu. Charakterystyczne, iż ponownie znaleźli się oni na ostatniej pozycji w hierarchii senatorów, być może przez wzgląd na zachowanie odpowiedniej równowagi prestiżu między poszczególnymi organami władzy ${ }^{61}$.

Należy pamiętać, że w dobie Sejmu Wielkiego prestiż senatorskich i ministerialnych funkcji pozostawał kwestią wysoce ambiwalentną, prze-

${ }^{59}$ Sesja 210 z 2 XI 1808, w: ibidem, t. 1, cz. 2, s. 206-207.

${ }^{60}$ Znamienne, że jeszcze w drugiej połowie XIX w. heraldycy i genealodzy, którzy podliczali indywidualne dostojeństwa mające świadczyć o wielkości (magnackości) danego rodu, traktowali województwa, kasztelanie i ministerstwa z lat 1807-1831 na równi z przedrozbiorowymi. Czynili tak chociażby Seweryn Uruski i Adam Amilkar Kosiński.

${ }^{61} \mathrm{Na}$ temat Senatu oraz opinii o senatorach w tym okresie patrz: R. Łaszewski, Sejm polski w latach 1764-1793, Warszawa 1973, s. 62-71; A. Grześkowiak-Krwawicz, o formę rządu czy o rząd dusz? Publicystyka polityczna Sejmu Czteroletniego, Warszawa 2000, s. 355-357. Por. także: J. Michalski, Problematyka polskiej elity politycznej XVIII wieku, „Wiek Oświecenia” 5, 1988, s. 19-26. 
de wszystkich ze względu na ich bezpośrednie uzależnienie od władcy (z zasady podejrzewanego o zapędy absolutystyczne). Był to wszakże moment wyraźnego wzrostu społecznego uznania dla poselstwa, zdecydowanie przewyższającego tradycyjny prestiż Senatu ${ }^{62}$. W ostatecznym rozrachunku, zgodnie z postanowieniami Ustawy Rządowej, naczelny autorytet izby poselskiej jako „wyobrażenia i składu wszechwładztwa narodowego" został definitywnie potwierdzony. Jednak generalna modernizacja państwa w oparciu o modne w ówczesnej Europie rozwiązania konstytucyjnego monarchizmu bynajmniej nie deprecjonowała pozycji senatorów i ministrów w równym stopniu. Racjonalne docenienie znaczenia sprawnej władzy wykonawczej dla funkcjonowania struktury państwowej przesądzało o swego rodzaju „łasce w niełasce”, a więc wyróżnieniu ministrów na szkodę senatorów. Tym ostatnim w zakresie kompetencji politycznych pozostawało jedynie (choć pod pewnymi względami aż) weto zawieszające wobec uchwał poselskich. Fakt, że majowe rozwiązania nigdy nie zostały wprowadzone w życie, nie pozwala ocenić, czy pozostający w stanie wielkosejmowej euforii reformatorzy, a zwłaszcza popierająca Konstytucję herbowa masa (zarówna ta parlamentarna, jak i sejmikowa), zdawali sobie sprawę z pozapolitycznych konsekwencji podobnych rozwiązań.

Bez względu na pozytywną lub negatywną odpowiedź na to pytanie, w Księstwie kontekst analogicznej refleksji był zupełnie odmienny. Przede wszystkim inaczej patrzono już na kwestię przedrozbiorowej tradycji, co dość jasno obrazuje ukazana powyżej dyskusja w sprawie precedencji. Jak nigdy przedtem napoleońska konstytucja jednoznacznie usankcjonowała senatorsko-ministerialny „rozwód”. W gruncie rzeczy nie istniała pomiędzy tymi urzędami żadna płaszczyzna zależności (co znamienne, członkowie rządu weszli w skład tradycyjnie silniejszej izby poselskiej). Jedynym elementem, który je łączył, była osoba króla-księcia, pełniącego funkcję rozdawcy stanowisk obu kategorii.

Jednak charakter zależności między królem z jednej strony a senatorami i ministrami z drugiej nie był (i nie mógł być) tożsamy. W sposób szczególny przejawiało się to w kwestii pierwszeństwa przewodniczących Senatu oraz Rady Stanu (i Ministrów). O ile prezes tej ostatniej był jedynie reprezentantem monarchy, niemającym żadnych prerogatyw i w pełni uzależnionym od jego rozkazów, prawnoustrojowa sytuacja prezesa Senatu (a zarazem i senatorów) była diametralnie odmienna. Integralny związek między izbą wyższą parlamentu a królem był faktem, ale z formalnego punktu widzenia miał raczej charakter honorowy. Kompetencje

${ }^{62} \mathrm{~J}$. Kowecki, Posłowie debiutanci na sejmie czteroletnim, w: Wiek XVIII. Polska i świat, red. A. Zahorski, Warszawa 1974, s. 195-210. 
króla ograniczały się do nominacji i ewentualnego przewodnictwa obradom senatorów. Nie mógł im niczego narzucić, w przeciwieństwie do ministrów, którzy bezpośrednio podlegali jego rozkazom. Delegacja członków Senatu wyznaczonych do konkretnych czynności (np. jako komisarzy do specjalnych poruczeń $)^{63}$ również nie dawała królowi szczególnych kompetencji w tym zakresie. Natomiast władza prezesa Rady Stanu i Ministrów formalnie kończyła się w chwili postawienia monarszej stopy na ziemi Księstwa. W efekcie najpóźniejszy ze znanych projektów uznawał wyższość prezesa Senatu jedynie w przypadkach obecności króla.

W warszawskich realiach dowartościowanie w ten sposób pozycji prezesa Senatu nie miało większego znaczenia nawet w sferze czysto ceremonialnej. Stała nieobecność władcy uczyniła z prezesury Rady urząd o charakterze permanentnym. W zasadzie to król od czasu do czasu wyręczał go w prezesowskich obowiązkach ${ }^{64}$. W sytuacji scentralizowanego monarchizmu napoleońskiego nadrzędność majestatu była niepodważalna, dlatego prezes Senatu był zmuszony zaakceptować wyższość królewskiego substytutu w osobie przewodniczącego Rady. Podrzędność senatorów w stosunku do ministrów była już tylko logicznym następstwem tej sytuacji. Ministrowie pozostawali stale zatrudnieni przy egzekucji praw w danym, ściśle wydzielonym dla siebie obszarze. Ich zadaniem było wyręczać monarchę w kwestiach szczegółowych, jednak on sam nie mógł się w praktyce bez nich obyć. Tak jak przed rozbiorami ranga ministrów pozostawała w nierozerwalnym związku z konstytucyjną pozycją króla.

W efekcie najwyższy prestiż senackiej godności stawał się jedynie teoretyczny, jeżeli nie wręcz pozorny. Co prawda, przed rozbiorami stanowisko senatorskie $\mathrm{z}$ formalnego punktu widzenia nie zapewniało żadnych poważniejszych kompetencji politycznych (w każdym razie bynajmniej nie większych niż za czasów Księstwa), specyfika ustroju i kultury politycznej zapewniała senatorom-ministrom społeczno-polityczną dominację. Tymczasem w napoleońskich realiach Księstwa, gdzie władza i wpływy polityczne stały się monopolem scentralizowanej biurokracji (a przynajmniej wkrótce miało się tak stać zgodnie z planami rządu), senatorom pozostała prestiżowo ambiwalentna pozycja niezależnego obserwatora, dodatkowo podbudowana wciąż silnym sentymentem wobec przeszłości. Jednak mi-

${ }^{63}$ Tak jak w przypadku senatorskich delegacji do Bajonny w 1808 r., na ślub Napoleona z Marią Luizą w 1810 r. czy w celu powitania cesarza w granicach Księstwa w $1812 \mathrm{r}$.

${ }^{64} \mathrm{Na}$ temat kompetencji ministrów oraz Rady Stanu i Rady Ministrów patrz: M. Kallas, Konstytucja Księstwa Warszawskiego, Toruń 1970, s. 80-101. Por. również M. Krzymkowski, Rada Stanu Księstwa Warszawskiego, Poznań 2011. 
nistrowie mieli w tej samej sytuacji zarówno jedno i drugie - dostęp do faktycznej władzy oraz staropolski prestiż. O społecznym znaczeniu tej zmiany dodatkowo przekonuje nas sytuacja z okresu Królestwa Polskiego, w którym ten napoleoński rozdział został w pełni utrzymany. Senatorskie krzesło mogło co najwyżej potwierdzić wysoką pozycję społeczną, jednak samo w sobie nie czyniło z nikogo „wielkiego pana”, jak to bywało przed rozbiorami ${ }^{65}$.

Ostatecznie, precedencja nie została wprowadzona ani w Księstwie ani w Królestwie, choć system polityczny tego ostatniego (i jego ścisłe związki z Rosją, gdzie funkcjonowała tabela rang) raczej sprzyjał podobnym rozwiązaniom. Wydaje mi się, że trudno uznać tę sytuację za przypadkową. Rozbieżność obu modeli ustrojowych, przed- i porozbiorowego, była najwidoczniej tak znaczna, że aż niemożliwa do pogodzenia. Ścisła hierarchia, obejmująca ogół stanowisk publicznych (administracyjnych, wojskowych, parlamentarnych, samorządowych), zaprzeczała wyobrażeniom szlacheckiej elity o strukturze „odrodzonego” państwa polskiego.W tak drastycznie zmienionej rzeczywistości polityczno-społecznej uczyniono przynajmniej tyle, aby zachować pozór łączności z przeszłością.

\section{"Supreme Office Next to the Throne" - Napoleonic Centralism and the Concept of the Elite in the Duchy of Warsaw}

The article deals with the conception of political (social) life in the Duchy of Warsaw (1807-1813/1815) at a time of revolutionary changes of the heretofore character of public service in the Polish state "resurrected" by Napoleon. The titular problem is illustrated by an unrealised attempt at establishing a precedence of offices, unknown in pre-partition tradition and referring to analogous French solutions. This venture was to encompass all public offices (administrative, military, court, parliamentary and self-government functions), with only a few referring (mainly via their names) to posts from the period of the Commonwealth of Two Nations. The prime object of the analysis is a collection of projects preserved at the Central Archives of Historical Records in Warsaw. The fundamental difference comes down to establishing priority in the hierarchy of offices - the senators and chairman of the Senate or the ministers and chairman of the Council of State and Council of Ministers. Their ability to make an unambiguous decision stemmed from the different character of the offices of ministers directly dependent on the absolute monarch and representing modern centralised bureaucracy, and the

${ }^{65}$ Przede wszystkim w odniesieniu do wojewodów i tzw. kasztelanów krzesłowych, czyli wojewódzkich. Kasztelanie drążkowe (powiatowe) były mniej poważane, choć i tak zdecydowanie wynosiły utytułowanych ponad średniozamożne szlacheckie środowisko. W drugiej połowie XVIII w. ich ranga znacznie wzrosła m.in. z powodu oficjalnego zniesienia podziału na dwa typy kasztelanów. 
independent senators closer to Old Polish anti-monarchic traditions. By locating the discussion within a wider context of socio-systemic transformations at the beginning of the nineteenth century, the author demonstrated the way in which the drastically altered political situation (preserving, however, the appearances of a return to the past) influenced the views of men of the period concerning the elite of the "resurrected" Polish state.

Translated by Aleksandra Rodzińska-Chojnowska 